\title{
INTRODUCTION OF A PARASITOID FOR MEALYBUG BIOCONTROL: A CASE STUDY UNDER NEW ENVIRONMENTAL LEGISLATION
}

\author{
J. CHARLES \\ HortResearch, Private Bag 92 169, Auckland \\ Corresponding author: jcharles@hortresearch.co.nz
}

\begin{abstract}
Pseudaphycus maculipennis is one of the few known encyrtid parasitoids of the obscure mealybug (Pseudococcus viburni). It was released in New Zealand on 14 February 2001. The importation process under changing environmental legislation over an 8 year period is detailed and the implications of the new legislation for future classical biocontrol programmes is discussed.

Keywords: mealybug, biocontrol, legislation.
\end{abstract}

\section{INTRODUCTION}

The first biocontrol agent to be released into New Zealand under the Hazardous Substances and New Organisms Act (HSNO) 1996 was the encyrtid parasitoid Pseudaphycus maculipennis (Mercet). The target pest for the biocontrol project was the obscure mealybug Pseudococcus viburni (Signoret). The process took place during a period of major change in New Zealand's environmental legislation, and involved the Animals Act 1967, the Biosecurity Act 1993 and the HSNO Act. This paper documents the process, and discusses some implications for the future.

Biology of Pseudococcus viburni and Pseudaphycus maculipennis

Obscure mealybug, is a polyphagous, cosmopolitan pest (Ben Dov 1994), probably introduced to New Zealand through commercial trade. It was first recorded in 1922 as P. maritimus (Charles 1998) and is now one of the commonest exotic mealybugs in New Zealand. It has been an important pest of pipfruit in Hawke's Bay for at least 50 years (Charles 1989). Although broad-spectrum organophosphate insecticides have now been removed from pipfruit export spray schedules, targeted mealybug control measures, such as specific insecticides and natural enemies, are still required.

P. maculipennis (Mercet 1923) is probably native to the Southern European/ Mediterranean region. It was first documented as a biocontrol agent for obscure mealybug in the south of France (Panis \& Brun 1971; Panis 1981). It was released into the Republic of Georgia in about 1976, where it also controlled obscure mealybug (Yasnosh \& Mjavanadze 1983), and was released into the Granite Belt and coastal areas of Queensland, AustraIia in November 1997 (F. Page, pers. comm.).

Importation of $P$. maculipennis into quarantine and application to release

Approval to import $P$. maculipennis from Europe was granted in November 1994 (MAF permit no: G94/INV/12) but the source laboratory colonies died before any importations were made. A second permit was issued by MAF Quality Management on 12 September 1997 (permit no: 1997000400, replaced by 1997001049 on 10 November 1997) and P. maculipennis was imported from a laboratory colony in Australia into the Mt Albert Invertebrate Quarantine Facility on 12 December 1997. Dr J.S. Noyes of the Natural History Museum, London, confirmed the parasitoid's identity, and voucher specimens were deposited in the New Zealand Arthropod Collection.

The application process took place during a period of major change in New Zealand's environmental legislation. Permit G94/INV/12 was issued in accordance with the Animals Act 1967 and Permit 1997001049 in accordance with the Biosecurity Act. Pseudaphycus 
maculipennis was imported into quarantine under the Biosecurity Act prior to the implementation of the HSNO Act. Host-testing was completed by April 1999, and application to release was made to the Environmental Risk Management Authority (ERMA) in accordance with the HSNO Act. Over the next 13 months, the application proceeded along a regulated pathway (Table 1). Further technical information was required by ERMA New Zealand (the bureaucracy supporting ERMA), as was extensive consultation culminating in a public hearing in May 2000. Approval to release P. maculipennis was given in August 2000. Finally, Biosecurity Clearance was obtained from MAF Regulatory Authority, and ERMA was notified that $P$. maculipennis had been released from containment.

TABLE 1: Timetable for approval to release Pseudaphycus maculipennis.

\begin{tabular}{|c|c|}
\hline Date & Action \\
\hline 1993 & $\begin{array}{l}\text { Publication of research showing the need for an encyrtid } \\
\text { parasitoid against obscure mealybug. }\end{array}$ \\
\hline November 1994 & $\begin{array}{l}\text { First permit to import } P \text {. maculipennis into quarantine issued } \\
(M A F \text { Animals Act). }\end{array}$ \\
\hline 12 September 1997 & $\begin{array}{l}\text { Second permit to import } P \text {. maculipennis into quarantine } \\
\text { issued (MAF Animals Act). }\end{array}$ \\
\hline 10 November 1997 & Second permit replaced (Biosecurity Act). \\
\hline 12 December 1997 & P. maculipennis imported into quarantine for host testing. \\
\hline 16 April 1999 & $\begin{array}{l}\text { Application to release } P \text {. maculipennis from quarantine } \\
\text { formally received by ERMA New Zealand (HSNO Act). }\end{array}$ \\
\hline 29 April 1999 & $\begin{array}{l}\text { Application stalled pending provision of further relevant } \\
\text { information (section 52(1) of HSNO Act). }\end{array}$ \\
\hline 15 December 1999 & Application re-submitted to ERMA NZ(HSNO Act). \\
\hline 21 December 1999 & Application verified by ERMA NZ(HSNO Act). \\
\hline 22 January 2000 & $\begin{array}{l}\text { Application publicly notified in The Dominion, The New } \\
\text { Zealand Herald, The Press and The Otago Daily Times } \\
\text { (HSNO Act). }\end{array}$ \\
\hline 3 March 2000 & Public submissions closed (HSNO Act). \\
\hline 27 April 2000 & $\begin{array}{l}\text { Report to ERMA from Nga Kaihautu Tikanga Taiao received } \\
(H S N O A c t) \text {. }\end{array}$ \\
\hline 9 May 2000 & $\begin{array}{l}\text { Public Hearing of application by Special Committee of } \\
\text { ERMA (HSNO Act). }\end{array}$ \\
\hline 19 May 2000 & $\begin{array}{l}\text { Further independent taxonomic information requested by } \\
\text { ERMA (HSNOAct). }\end{array}$ \\
\hline 4 August 2000 & $\begin{array}{l}\text { Release of } P \text {. maculipennis approved and publicly notified } \\
(H S N O A c t) \text {. }\end{array}$ \\
\hline 1 September 2000 & Biosecurity Clearance approved (MAF, Biosecurity Act). \\
\hline 5 September 2000 & $\begin{array}{l}\text { ERMA NZ notified of release of } P \text {. maculipennis from } \\
\text { quarantine (HSNO Act) }\end{array}$ \\
\hline 14 February 2001 & $\begin{array}{l}\text { First } P \text {. maculipennis released into obscure mealybug infested } \\
\text { orchard in Hawke's Bay. }\end{array}$ \\
\hline
\end{tabular}

\section{Release of $P$. maculipennis}

A programme to release $P$. maculipennis into orchards was initiated in September 2000. Obscure mealybug and $P$. maculipennis were reared on sprouting potatoes, and the first of several releases (at ca 25000 per property) to Hawke's Bay apple orchards during the summer of 2001 was made on 14 February.

A planned, extensive release programme, followed by parasitoid establishment and impact measurements for at least two years, will be reported elsewhere in due course. Once established, P. maculipennis is expected to show a favourable numerical and 
functional response to obscure mealybug populations both inside and outside orchards, and to become an integral part of Integrated Fruit Production programmes, especially in apple and pear orchards. The parasitoid's presence will help to further reduce the use of broad-spectrum insecticides and hence the environmental impact of conventional orcharding. It will also assist organic pipfruit growers who currently have no effective natural control options for obscure mealybug. Ultimately it is expected to increase the export value of all pipfruit crops.

\section{DISCUSSION}

The application to release $P$. maculipennis was unique in that the timetable spanned two approval systems - the "old" (MAF/Animals Act) and the "new" (ERMA/ HSNO Act). The underlying differences between these two systems reflect the social and political importance given to environmental protection during the 1990s. In practice, the impact of the new legislation was most apparent in four areas:- the amount of technical and background information required, the cost of applications, the requirement for public and Maori consultation, and the often emotive issue of host-specificity.

The HSNO Act is very knowledge-demanding. ERMA requires an intensive and extensive account of the natural enemy, its intended host, its impact on the environment, its impact on non-target organisms, and a cost-and-risk/benefit analysis of its introduction. The provision of acceptably robust economic and risk data in the absence of dollar values for the environment and the uncertainties of biological interactions will provide an ongoing challenge. However, there is no doubt that extra data does provide a more robust and more transparent case upon which a decision can be made.

The HSNO Act has very substantially increased the cost of biocontrol applications. The ecological data required by ERMA have to relate to New Zealand's society and environment. As there are almost always insufficient relevant data from existing international programmes, they must be collected, either in quarantine in New Zealand or in the country of origin of the pest/natural enemy. These research costs may be substantial. In addition, the fees directly payable to ERMA are high. ERMA is expected to recover a large proportion of its costs, and, as biocontrol programmes are unique with many uncertain values, the application fees are open-ended. Currently, fees of between NZ\$30-50,000 per application can be expected. Consequently, the budget for an apparently uncomplicated programme to import a single biocontrol insect for a fruit crop pest should allow about NZ $\$ 250,000$ just to reach the stage of approval to release. The additional costs of establishment and impact assessment over the next few years are likely to be at least the same again.

The HSNO Act requires applicants to consult with the public, and specifically and separately with Maori. Consultation that is of value to iwi both locally and nationally brings a new and challenging social dimension to biocontrol. It may take a while to determine just what is expected by "consultation". It is certainly more than informing local iwi of the existence of a biocontrol programme. It possibly should include ongoing dialogue and education at both regional and national levels. Effective consultation also requires feedback from Maori, which potentially exposes biocontrol programmes to Waitangi tribunal claims, such as WAI 262, the intricacies of inter-iwi politics, and broader issues such as te tino rangatiratanga (sovereignty) vs kawanatanga (governance).

In recent years, the perceived lack of host-specificity of classical biocontrol agents has become a central and often emotive issue of public debate. At the root of these concerns is the fact that multi-trophic interactions are so complex that there is a limit to the degree of predictability and certainty that ecological science can provide. So some groups articulate fears that all biocontrol agents pose a threat to the environment, and that classical biocontrol programmes should not proceed without unequivocal proof of monophagy.

The application for P. maculipennis was, (together with one for Thripobius semiluteus to control greenhouse thrips, Heliothrips haemorrhoidalis) the first test of many of the requirements of the HSNO Act. As ERMA's decisions set precedents for the future, the 
applications were extremely carefully considered. Despite the concerns of some, or hopes of others, that ERMA might apply 'precautionary principles' and prohibit the release of any new biological control agents into New Zealand, this has not happened. By April 2001 ERMA had approved the release of three insects (the two above and the tephritid fly Procecidochares alani for mist flower control) as biocontrol agents, giving considerable assurance that biocontrol agents will not be rejected out of hand because of ecological uncertainties. However, these approvals were for three extremely host-specific insects . Two concerns are: (1) What extent of oligophagy or polyphagy in a biocontrol agent will be acceptable to ERMA? and (2) How will ERMA view the risk of a second or third parasitoid, when one natural enemy has already been introduced?

As the costs of biocontrol programmes has increased so significantly to cover the research, fees and consultation required by the HSNO Act, so the future for biocontrol in New Zealand has been questioned. Yet growers, politicians and environmentalists all agree that New Zealand should maintain horticultural and agricultural export industries with a 'clean, green' image. This means that growers will have to control new and existing exotic pests with fewer (or no) pesticides, while surmounting higher and higher quarantine barriers to export markets. The answer, then, to the question "is there a need for biocontrol programmes?" has to be an emphatic "yes". For many pests, biological control may provide the only effective and sustainable means of control. For many others, a guild of natural enemies will contribute to the long-term ecological stability of both productive and indigenous ecosystems. If the need is acknowledged, then who should pay for biocontrol? If the answer is to be found in the maxim "the user pays", then who are the users and how can the maxim be fairly applied? Any analysis to support the interpretation that farmers or orchardists are the major beneficiaries of biocontrol seems to be lacking. Should fruit-growers alone have to pay for a programme, if the rest of the region - or indeed the country - also benefits from the industry? And who are the 'users' to pay for environmental pests? If society as a whole should fairly pay for biocontrol research, through, for example, the Public Good Science Fund, then the Foundation for Research, Science and Technology should have a well thought-through process for allocating funding for ecological research across both productive and indigenous ecosystems.

If biocontrol does have a future, then what will be the role of entomologists? They will, of course, be expected to continue to provide the ecological data that is central to every programme and application. In addition they will be expected to play a major role in education, consultation, advocacy and liaison between various government departments, bureaucracies and the public. Biocontrol entomologists will have to develop new skills in public participation, as well as increasing their skills in, and international knowledge of, population and community ecology.

\section{REFERENCES}

Ben-Dov, Y. 1994: A systematic catalogue of the mealybugs of the world. Intercept Ltd., UK. $686 \mathrm{p}$.

Charles, J.G. 1989: Pseudococcidae, mealybugs (Homoptera). In: Cameron, P.J. ., Hill, R.L., Bain, J. and Thomas, W.P. ed. A review of Biological Control of invertebrate pests and weeds in New Zealand 1874 -1987. Tech. Comm. CAB International, UK. Pp. 223-236.

Charles, J.G. 1993: A survey of mealybugs and their natural enemies in horticultural crops in North Island, New Zealand, with implications for biological control. Biocontrol, Sci. Technol. 3: 405-418.

Charles, J.G. 1998: The settlement of fruit crop arthropod pests and their natural enemies in New Zealand: an historical guide to the future. Biocontrol News Info. 19: 47N$58 \mathrm{~N}$.

Charles, J.G.; Walker, J.T.S. 1981: Mealybug control in apples. Orchardist of New Zealand 54: $252-253$ 
Charles, J.G.; Walker, J.T.S; White, V. 1993: Resistance to chlorpyrifos in the mealybugs Pseudococcus affinis and P. longispinus in Hawkes Bay and Waikato pipfruit orchards. Proc. 46th N.Z. Plant Prot. Conf: : 120-125.

Congdon, N.B.; Morrison, L.G. 1959: Mealybug resurges in Hawke's Bay orchards. N.Z. J. Agric. 99: 481-487.

Panis, A.; Brun, J. 1971: Essais de lutte biologique contre trois especes de "Pseudococcidae" ("Homoptera, Coccoidea) en serres de plantes vertes. Rev. Zool. Agric. 70: 42-47.

Panis, A. 1981: Note sur quelques insectes auxiliaires régulateurs des populations de Pseudococcidae et de Coccidae (Homoptera, Coccoidea) des agrumes en Provence orientale. Fruits 36(1): 49-52.

Ward, A. 1966: Mealybugs (Hemiptera: Pseudococcidae) in Hawke's Bay orchards. N.Z. J. Agric. Res. 9: 452-454

Yasnosh, V.A.; Mjavanadze, V.I. 1983: On the efficiency and rational use of Cryptolaemus montrouzieri against plant pests in the Georgian SSR. Proc. 10th Int. Cong. Plant Prot., Brighton, UK. p. 798. 